\title{
Nilai Ekonomi Sampah di Kawasan Wisata Pantai Tanjung Bira, Sulawesi Selatan
}

\section{(Economic Value of Waste at Tanjung Bira Beach, South Sulawesi)}

\author{
Husnul Inayah, Asti Istiqomah* \\ (Diterima Agustus 2019/Disetujui Desember 2020)
}

\begin{abstract}
ABSTRAK
Pantai Tanjung Bira merupakan salah satu wisata bahari yang terletak di Kecamatan Bonto Bahari, Kabupaten Bulukumba, Sulawesi Selatan. Jumlah kunjungan wisatawan Pantai Tanjung Bira terus mengalami peningkatan selama lima tahun terakhir dengan laju pertumbuhan tertinggi pada tahun 2018, yaitu sebesar $27,58 \%$. Kondisi tersebut di satu sisi dapat meningkatkan perekonomian daerah, namun di sisi lain juga dapat memengaruhi kondisi lingkungan, seperti peningkatan jumlah timbulan sampah yang ada di kawasan wisata tersebut, baik sampah organik maupun anorganik. Tujuan penelitian ini adalah: 1) Mengidentifikasi potensi timbulan sampah yang dihasilkan kawasan wisata Pantai Tanjung Bira; dan 2) Mengestimasi nilai ekonomi sampah di kawasan wisata Pantai Tanjung Bira. Metode analisis yang digunakan ialah analisis deskriptif kuantitatif dan metode valuasi. Hasil penelitian menunjukkan bahwa potensi timbulan sampah dari kegiatan wisata di kawasan wisata Pantai Tanjung Bira adalah sebesar $16.908,86 \mathrm{~kg} /$ tahun yang mayoritas dihasilkan oleh wisatawan. Jenis sampah yang dihasilkan didominasi oleh sampah plastik, baik yang bersumber dari wisatawan maupun dari pelaku usaha. Total nilai ekonomi sampah kawasan wisata Pantai Tanjung Bira adalah Rp20.298.215/tahun, yang berasal dari sampah anorganik tidak diolah sebesar $97,60 \%$, potensi plastik cacah sebesar $1,75 \%$, dan potensi kompos sebesar $0,64 \%$.
\end{abstract}

Kata kunci: nilai ekonomi, timbulan sampah, wisata bahari

\section{ABSTRACT}

Tanjung Bira Beach is one of the marine tourisms located in the Bonto Bahari District, Bulukumba Regency, South Sulawesi. The number of tourists visiting Tanjung Bira Beach has continued to increase over the past five years with the highest growth rate in $\mathbf{2 0 1 8}$ at the level of $\mathbf{2 7 . 5 8 \%}$. This condition can improve the regional economy, but on the other hand it can also affect environmental conditions such as the increasing amount of waste generation in the tourism area, both organic and inorganic wastes. The objectives of this study are: 1) Identifying the potential of waste generation in Tanjung Bira Beach tourist area; and 2) Estimating the economic value of waste in the tourist area of Tanjung Bira Beach. The analytical method used was quantitative descriptive analysis and valuation method. The results showed that the potential for waste generation from tourism activities in the Tanjung Bira Beach tourist area were $16908.86 \mathrm{~kg} / \mathrm{year}$, with the majority of the wastes were generated by tourists. The type of waste generated was dominated by plastic waste both from tourists and local business. The total economic values of garbage in the Tanjung Bira Beach tourism area were IDR 20298215/year, which $97.60 \%$ came from inorganic waste, $1.75 \%$ from potential plastic waste, and $0.64 \%$ from compost potential.

Keywords: economic value, waste stacks, marine tourism

\section{PENDAHULUAN}

Indonesia memiliki potensi modal alam yang dapat menjadi daya tarik pariwisata, seperti laut, pantai, gunung, danau, dan hutan. Pariwisata berperan penting dalam kehidupan manusia karena sangat terkait dengan kegiatan ekonomi dan sosial, sebagaimana telah diakui oleh badan organisasi internasional, seperti World Bank, Perserikatan Bangsa Bangsa, dan World Tourism Organization (WTO) (Nurmansyah 2014). Wisata bahari merupakan salah satu wisata di Indonesia yang memiliki potensi

Departemen Ekonomi Sumberdaya dan Lingkungan, Fakultas Ekonomi dan Manajemen, Institut Pertanian Bogor, Kampus IPB Darmaga, Bogor 16680

* Penulis Korespondensi: Email: asti.istiqomah@gmail.com besar untuk dikembangkan. Salah satu wilayah yang memiliki banyak potensi wisata bahari ialah Provinsi Sulawesi Selatan. Pariwisata bahari merupakan salah satu alternatif pariwisata berkelanjutan yang memiliki aspek ekonomi, sosial-budaya, dan lingkungan (Subadra \& Nadra 2006).

Kabupaten Bulukumba merupakan salah satu kabupaten di Provinsi Sulawesi Selatan yang memiliki potensi wisata bahari yang menarik untuk dikunjungi. Salah satu wisata bahari di sana ialah Pantai Tanjung Bira. Pantai Tanjung Bira terletak di Kecamatan Bonto Bahari bagian selatan pulau Sulawesi dan berjarak kurang lebih 45 kilometer dari Kota Bulukumba (Maryono 2017).

Total kunjungan wisatawan di Pantai Tanjung Bira terus mengalami peningkatan yang laju pertumbuhan tertinggi terjadi pada tahun 2018, yaitu sebesar 
27,58\%. Wisatawan di wilayah Pantai Tanjung Bira didominasi oleh wisatawan nusantara. Pada tahun 2018, jumlah wisatawan nusantara mencapai sebanyak 238.810 orang, sedangkan wisatawan mancanegara hanya sebanyak 3.555 orang. Perubahan jumlah wisatawan setiap tahun dapat dipengaruhi oleh pola keluar-masuk wisatawan, yaitu pada kondisi low visit (hari biasa), condenset visit (sabtu), dan peak visit (minggu), ataupun pada hari libur (Maryono 2017).

Peningkatan jumlah kunjungan wisatawan di satu sisi dapat meningkatkan perekonomian daerah, namun di sisi lain dapat menimbulkan eksternalitas negatif berupa sampah dari kegiatan wisata yang dapat menurunkan kualitas lingkungan. Sampah di kawasan wisata dapat berupa sampah organik dan sampah anorganik. Contoh sampah organik dari kegiatan wisata adalah sisa-sisa makanan dan sisa-sisa tumbuhan, sedangkan sampah anorganik yang dihasilkan dari kegiatan wisata adalah sampah plastik, kertas, logam, dan kaca (Crisdianti 2017). Eksternalitas tersebut terjadi apabila tindakan individu atau sekelompok individu wisatawan memengaruhi utilitas pihak lain (Fauzi 2014).

Sampah yang tidak dikelola dengan baik akan memengaruhi kebersihan dan kenyamanan lingkungan wisata. Sampah yang terdapat pada objek wisata bahari dapat menggangu pemandangan maupun daya tarik wisatawan. Lingkungan kawasan wisata yang kotor juga dapat berpengaruh pada minat wisatawan dalam menikmati kawasan wisata tersebut. Kondisi ini dapat berpotensi menurunkan jumlah kunjungan wisatawan sehingga penerimaan yang akan diperoleh dari kegiatan wisata juga akan menurun. Hal ini terjadi karena kunjungan wisatawan berpengaruh signifikan pada perolehan pendapatan suatu daerah (Pertiwi 2014). Selain itu, wisata juga memberikan efek multiplier yang relatif besar (Arianti 2014; Hastuti \& Diah 2018). Banyak wisatawan lokal yang berkunjung ke kawasan wisata Pantai Tanjung Bira merasa tidak puas karena merasa bahwa harga tiket yang dibayarkan tidak sebanding dengan kualitas lingkungan wisata tersebut, serta jumlah tempat sampah tidak sebanding dengan luas area kawasan wisata Pantai Tanjung Bira (Maryono et al. 2016).

Salah satu permasalahan lingkungan yang terjadi di kawasan wisata Pantai Tanjung Bira ialah sampah yang masih banyak ditemukan di lokasi pantai (Susilawati et al. 2016). Akan tetapi, pengelolaan sampah di kawasan wisata Pantai Tanjung Bira pada saat ini masih dilakukan oleh pihak pengelola yang hanya sebatas pengangkutan saja. Padahal, apabila sampah tersebut dikelola dengan baik maka sampah tersebut berpotensi menghasilkan nilai ekonomi. Potensi nilai ekonomi diperoleh dari hasil penjualan langsung sampah atau bisa juga dari pengolahan sampah terlebih dahulu untuk menghasilkan produk seperti plastik cacah atau kompos. Tujuan penelitan ini adalah mengidentifikasi potensi timbulan sampah yang dihasilkan di kawasan wisata Pantai Tanjung Bira dan mengestimasi nilai ekonomi sampah di kawasan wisata Pantai Tanjung Bira.

\section{METODE PENELITIAN}

\section{Lokasi dan Waktu Penelitian}

Penelitian dilakukan di kawasan wisata Pantai Tanjung Bira, Desa Bira, Kecamatan Bonto Bahari, Kabupaten Bulukumba, Provinsi Sulawesi Selatan. Pemilihan lokasi dilakukan dengan sengaja berdasarkan pertimbangan bahwa objek wisata tersebut memiliki tingkat kunjungan yang relatif tinggi dibandingkan dengan objek wisata sejenis di sekitarnya. Pengambilan data primer dan data sekunder dilakukan pada bulan Februari-Maret 2019.

\section{Jenis dan Sumber Data}

Data yang digunakan pada penelitian ini ialah data primer dan data sekunder. Data primer diperoleh dengan melakukan wawancara kepada wisatawan dan pelaku usaha di kawasan wisata Pantai Tanjung Bira dan stakeholder yang terkait. Data sekunder terdiri atas keadaan wilayah penelitian yang diperoleh dari kantor Kecamatan Bonto Bahari, data jumlah kunjungan, dan data jumlah pelaku usaha yang didapatkan dari Dinas Pariwisata Bulukumba, serta berbagai pustaka yang relevan dengan penelitian.

\section{Metode Pengambilan Sampel}

Pengambilan sampel untuk responden wisatawan menggunakan metode non-probability sampling, yaitu teknik pengambilan sampel yang tidak memberikan peluang yang sama bagi setiap anggota populasi untuk dipilih menjadi sampel (Sugiyono 2010). Pengambilan sampel wisatawan menggunakan teknik purposive sampling, dengan kriteria responden dipilih berdasarkan tujuan berwisata dan berusia di atas 17 tahun yang dapat berkomunikasi dengan baik. Jumlah wisatawan ditentukan dengan menggunakan rumus Slovin (Suharsaputra 2012) dengan tingkat eror $10 \%$ maka diperoleh jumlah sampel sebanyak 100 orang. Sementara itu, metode pengambilan sampel untuk responden pelaku usaha dilakukan dengan menggunakan metode non-probability sampling. Teknik pengambilan sampel menggunakan purposive sampling dengan kriteria keterwakilan jenis usaha dari masing-masing pelaku usaha (Tabel 1).

\section{Metode Analisis \\ - Identifikasi potensi timbulan sampah kawasan wisata pantai tanjung bira}

Timbulan sampah diestimasi dengan menghitung rata-rata bobot sampah masing-masing dari wisatawan dan dari pelaku usaha dan untuk setiap unit sampah diperoleh dengan cara menimbang masing-masing bobot sampah setiap unit sampah. Selanjutnya, dihitung rata-rata jumlah sampah yang dibawa oleh wisatawan dan pelaku usaha per unit. Bobot sampah untuk setiap unit sampah diperoleh dengan 
Tabel 1 Jumlah responden pelaku usaha

\begin{tabular}{lcr}
\hline \multicolumn{1}{c}{ Responden } & Populasi (orang) & Jumlah (orang) \\
\hline Pelaku usaha & & 12 \\
Makanan dan minuman & 51 & 4 \\
Souvenir & 11 & 8 \\
Pakaian & 18 & 8 \\
Jasa penyewa Banana Boat & 20 & 12 \\
Penyewa penginapan & 81 & \\
\hline
\end{tabular}

menimbang sampah di bank sampah terdekat. Formula perhitungan untuk mengetahui bobot sampah dari kegiatan wisata yang dihasilkan oleh wisatawan dan pelaku usaha di kawasan wisata Pantai Tanjung Bira adalah sebagai berikut:

- Wisatawan

a. Sampah yang bersumber dari luar kawasan wisata

$$
\mathrm{RBS}_{\mathrm{iL}}=\frac{B S_{i}}{n_{i}}
$$

Keterangan:

RBSiL = Rata-rata bobot sampah dari luar kawasan wisata (kg/unit)

$$
\begin{array}{ll}
\mathrm{BS}_{\mathrm{i}} & =\text { Bobot sampah }(\mathrm{kg}) \\
\mathrm{n}_{\mathrm{i}} & =\text { Jumlah sampah (unit) } \\
\mathrm{i} & =\text { Jenis sampah }
\end{array}
$$

$$
\mathrm{BTS}_{\mathrm{iL}}=\mathrm{RBS}_{\mathrm{i}} \times \frac{J R S}{J R} \times \mathrm{N}
$$

Keterangan:

$\mathrm{BTS}_{\mathrm{iL}}=$ Bobot timbulan sampah per jenis sampah dari luar kawasan wisata (kg/tahun)

JRS = Jumlah responden yang membawa sampah (orang)

JR = Jumlah responden total (100 orang)

$\mathrm{N} \quad=$ Populasi wisatawan tahun 2018 (orang)

b. Sampah yang bersumber dari dalam kawasan wisata

$$
\mathrm{RBS}_{\mathrm{iD}}=\frac{B S_{i}}{n_{i}}
$$

Keterangan:

$\mathrm{RBS}_{\mathrm{iD}}=$ Rata-rata bobot sampah (kg/unit) dari dalam kawasan wisata

$$
\mathrm{BTS} \mathrm{iD}=\mathrm{RBS}_{\mathrm{i}} \times \frac{J R S}{J R} \times \mathrm{N}
$$

Keterangan:

BTS $_{\mathrm{iD}}=$ Bobot timbulan sampah per jenis sampah dari dalam kawasan wisata ( $\mathrm{kg} /$ tahun)

- Pelaku usaha

$$
\mathrm{RBS}_{\mathrm{iP}}=\frac{B S_{i}}{n_{i}}
$$

Keterangan:

$\mathrm{RBS}_{\mathrm{iP}}=$ Rata-rata bobot sampah pelaku usaha (kg/unit)
$\mathrm{BTS}_{\mathrm{iP}}=\mathrm{RBS}_{\mathrm{iP}} \times \frac{J R S}{J R} \times \mathrm{N} \times \mathrm{WO}$

Keterangan:

BTS $_{i p}=$ Bobot timbulan sampah per jenis sampah dari pelaku usaha ( $\mathrm{kg} /$ tahun)

WO = Waktu operasional per jenis pelaku usaha (hari/tahun)

\section{Nilai Ekonomi Sampah di Kawasan Wisata Pantai Tanjung Bira}

Hasil data timbulan sampah kawasan wisata Pantai Tanjung Bira yang telah dikumpulkan kemudian dipisahkan antara jenis sampah organik dan anorganik. Sampah tersebut dipilah sesuai dengan klasifikasi sampah. Sampah yang memiliki harga jual akan dipisahkan menurut jenisnya, kemudian ditimbang serta nilai ekonominya dihitung dengan rumus sebagai berikut (Asdiantri et al. 2016).

$\mathrm{NES}=\mathrm{Q} \times \mathrm{P}_{\text {sampah }}$

Keterangan :

NES : Nilai Ekonomi Sampah (Rp/tahun)

Q : Timbulan Sampah (kg/tahun)

$P_{\text {sampah }}$ : Harga Jual Sampah (Rp/kg)

\section{HASIL DAN PEMBAHASAN}

\section{Jenis dan Jumlah Timbulan Sampah di Kawasan Wisata Pantai Tanjung Bira}

Jumlah sampah di kawasan wisata Pantai Tanjung Bira meningkat pada kondisi tertentu, yakni pada hari libur ataupun akhir pekan. Penumpukan sampah terjadi di sekitar lokasi pantai di mana lokasi tersebut merupakan titik keramaian wisatawan dan pelaku usaha. Identifikasi jenis dan jumlah sampah di kawasan wisata Pantai Tanjung Bira perlu dilakukan untuk melihat sejauh mana kegiatan wisata memberikan pengaruh pada kondisi lingkungan. Sementara itu, estimasi nilai ekonomi diperlukan sebagai pertimbangan dalam pengambilan kebijakan dalam pengelolaan sampah di lokasi wisata Tanjung Bira. Potensi timbulan sampah pada kawasan wisata Pantai Tanjung Bira dapat dilihat pada Gambar 1.

Perhitungan timbulan sampah di kawasan wisata Pantai Tanjung Bira dinyatakan dalam satuan bobot $(\mathrm{kg})$ per tahun. Jenis-jenis sampah yang terdapat pada kawasan wisata Pantai Tanjung Bira ialah sampah plastik, kaca, kaleng, kertas, styrofoam, dan organik. Total bobot timbulan sampah yang dihasilkan dari 


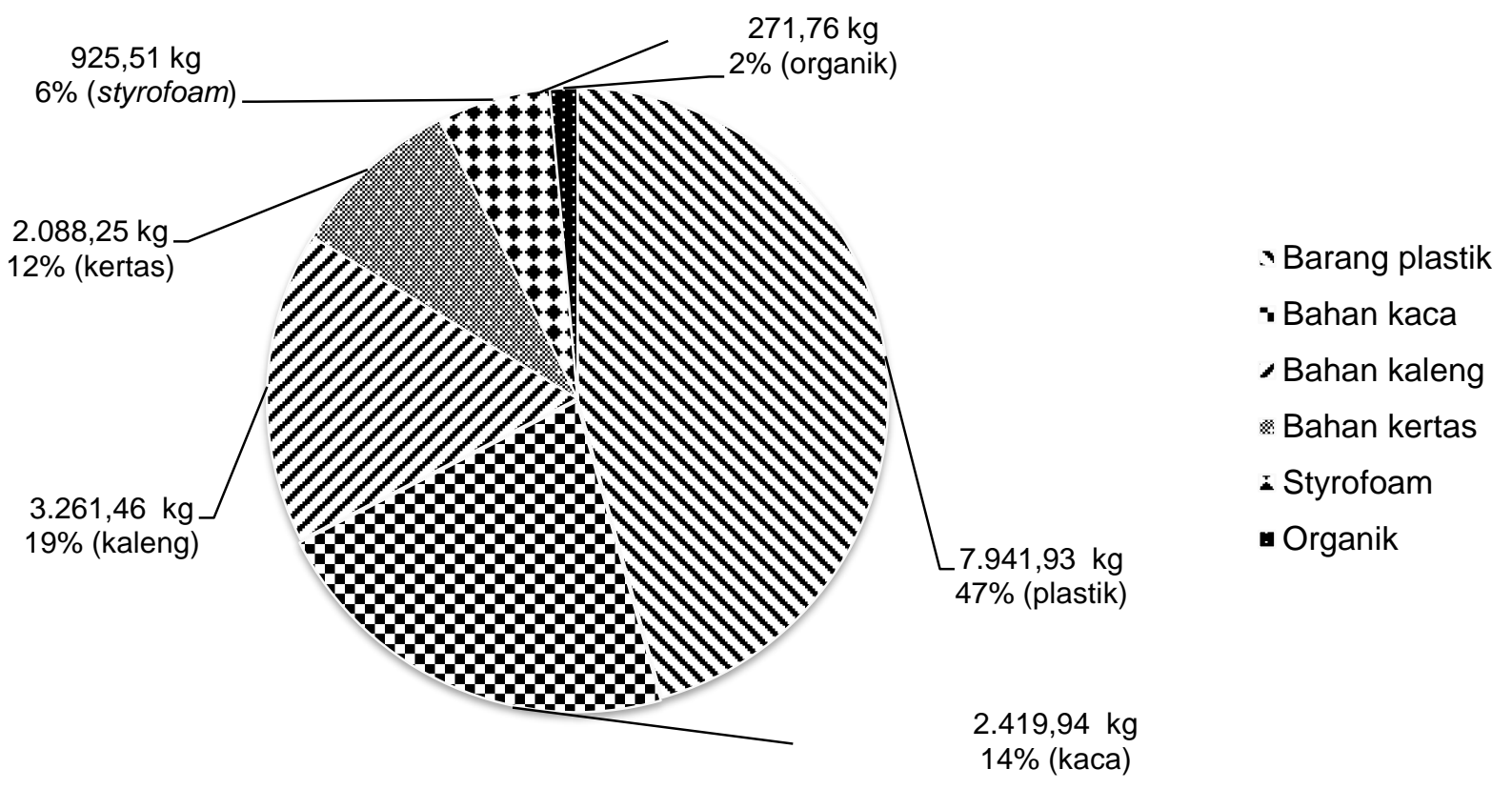

Gambar 1 Komposisi timbulan sampah di kawasan wisata Pantai Tanjung Bira.

kegiatan wisata Tanjung Bira adalah 16.908,86 $\mathrm{kg} /$ tahun. Komposisi timbulan sampah responden pada kawasan wisata Pantai Tanjung Bira didominasi oleh sampah anorganik, yaitu jenis barang plastik sebesar $47 \%$ dari total jumlah sampah, sedangkan komposisi timbulan sampah organik hanya $2 \%$ dari total jumlah sampah yang dihasilkan. Hal ini mengindikasikan bahwa apabila tidak ada pengelolaan yang baik akan membahayakan lingkungan dan ekosistem pantai dan laut. Karakteristik sampah plastik yang sulit untuk terurai atau membutuhkan waktu lama untuk terdegradasi menjadi permasalahan yang lebih kompleks. Penelitian dari Macquarie University di Australia telah meneliti efek plastik pada jenis bakteri laut fotosintesis yang disebut Prochlorococcus yang dipublikasikan dalam Jurnal Communications Biology. Hasil penelitian tersebut menyebutkan bahwa Prochlorococcus sangat penting untuk jaring makanan laut, yang berkontribusi pada siklus karbon, dan dianggap bertanggung jawab atas 10\% dari total produksi oksigen global.

Jenis dan Jumlah Sampah yang Berasal dari Wisatawan dan Pelaku Usaha di Kawasan Wisata Pantai Tanjung Bira

Jenis dan jumlah sampah yang berasal dari wisatawan diperoleh dengan menanyakan jenis dan jumlah barang yang berpotensi menjadi sampah, baik yang dibawa dari luar kawasan maupun yang dibeli di dalam kawasan. Perhitungan jumlah sampah yang berasal dari wisatawan dinyatakan dalam bentuk satuan bobot, yaitu kg dan diestimasi dalam satu tahun kunjungan. Responden wisatawan dapat menghasilkan sampah dari sisa konsumsi selama melakukan kegiatan wisata di Pantai Tanjung Bira. Jenis dan jumlah sampah wisatawan dapat dilihat pada Tabel 2.
Tabel 2 Jenis dan jumlah sampah yang berasal dari wisatawan di kawasan wisata Pantai Tanjung Bira

\begin{tabular}{lrrr}
\hline \multirow{2}{*}{$\begin{array}{c}\text { Jenis } \\
\text { sampah }\end{array}$} & \multicolumn{3}{c}{ Bobot sampah (kg/tahun) } \\
\cline { 2 - 4 } kawasan $^{*}$ & $\begin{array}{c}\text { Luar } \\
\text { kawasan }\end{array}$ & \multicolumn{1}{c}{ Total } \\
\hline $\begin{array}{l}\text { Barang } \\
\text { plastik }\end{array}$ & $2.035,34$ & $4.625,93$ & $6.661,27$ \\
$\begin{array}{l}\text { Bahan } \\
\text { kaleng }\end{array}$ & $1.385,09$ & $1.034,84$ & $2.419,94$ \\
Bahan & $1.480,62$ & $1.780,84$ & $3.261,46$ \\
kaca & & & \\
Bahan & 656,72 & 578,48 & $1.235,20$ \\
kertas & 39,8 & 831,41 & 871,21 \\
Styrofoam & 102,34 & 103,48 & 205,82 \\
\hline Organik & $5.699,94$ & $8.954,98$ & $14.654,93$ \\
\hline Total & &
\end{tabular}

Keterangan: * Barang yang dibeli di dalam kawasan wisata dan **Barang yang dibawa dari luar kawasan wisata

Berdasarkan Tabel 1, potensi total timbulan sampah wisatawan adalah sebanyak 14.645,93 $\mathrm{kg} / \mathrm{tahun}$. Sampah yang dihasilkan oleh wisatawan menyumbangkan sebesar $87,00 \%$ dari total sampah secara keseluruhan. Potensi timbulan sampah yang dihasilkan oleh wisatawan lebih didominasi oleh barang konsumsi yang dibawa dari luar kawasan wisata dengan total bobot 8.954,98 kg/tahun dari total bobot sampah wisatawan, sedangkan barang konsumsi yang dibeli di dalam kawasan wisata adalah $5.699,94 \mathrm{~kg} /$ tahun dari total bobot sampah wisatawan. Jenis sampah responden wisatawan didominasi oleh barang plastik yang mencapai 52,00\%, yang bersumber dari luar kawasan wisata Pantai Tanjung Bira.

Komposisi jenis sampah yang dihasilkan oleh wisatawan di kawasan wisata Pantai Tanjung Bira didominasi oleh sampah anorganik yang sulit terurai 
sehingga dapat berpotensi menimbulkan permasalahan lingkungan, berebeda dari sampah organik yang mudah terdekomposisi oleh aktivitas mikrorganisme (Darmawi 2017). Jenis sampah yang berasal dari wisatawan didominasi oleh barang plastik, baik yang dibawa dari luar ataupun yang diperoleh dalam kawasan wisata itu sendiri.

Berdasarkan Tabel 3 dapat dilihat bahwa potensi timbulan sampah yang dihasilkan oleh responden wisatawan lebih didominasi oleh barang konsumsi yang dibawa atau dibeli dari luar kawasan Pantai Tanjung Bira. Mayoritas wisatawan membawa barang konsumsi dari luar kawasan wisata yang berpotensi menjadi sampah dibandingkan dengan membeli langsung di dalam kawasan wisata yang dapat dilihat pada Tabel 3.

Responden wisatawan yang membawa barang konsumi berpotensi menjadi sampah yang berasal dari luar kawasan wisata serta dibeli langsung dalam kawasan wisata dengan sumbangan sebesar $46,00 \%$. Barang konsumsi yang dibawa dari luar kawasan wisata saja sebesar $39,00 \%$, dan barang konsumsi yang hanya dibeli dalam kawasan wisata sebesar $15,00 \%$ (Tabel 3).

Potensi timbulan sampah juga dapat dihasilkan dari pelaku usaha kawasan wisata Pantai Tanjung Bira selama melakukan aktivitas di tempat tersebut. Di Pantai Tanjung Bira, teridentifikasi terdapat lima jenis usaha, yaitu usaha makanan/minuman, souvenir, pakaian, penyewa banana boat, dan penyewaan penginapan. Jenis dan jumlah sampah yang dihasilkan oleh masing-masing pelaku usaha dapat dilihat pada Tabel 4.

Berdasarkan data pada Tabel 5, potensi timbulan sampah yang dihasilkan dari pelaku usaha adalah $2.253,92 \mathrm{~kg} /$ tahun, yang relatif lebih kecil dibandingkan dengan sampah yang dihasilkan oleh wisatawan. Sampah yang dihasilkan oleh pelaku usaha sebesar $13,00 \%$ dari total timbulan sampah kawasan wisata Pantai Tanjung Bira. Jenis sampah yang dihasilkan adalah barang plastik, kertas, styrofoam, dan bahan organik. Sama halnya dengan wisatawan, jenis sampah plastik paling banyak dihasilkan dari semua pelaku usaha. Unit usaha makanan/minuman dan penyewa penginapan menghasilkan banyak sampah plastik dibandingkan dengan unit usaha lain dengan persentasi jumlah sampah plastik masing-masing sebesar $43,00 \%$ dan $40,00 \%$ dari total sampah keseluruhan. Potensi timbulan sampah yang paling

Tabel 3 Sumber sampah dari wisatawan kawasan wisata Pantai Tanjung Bira

\begin{tabular}{|c|c|c|}
\hline Sumber sampah & Wisatawan & Persentase (\%) \\
\hline Dibawa dari luar & 39 & 39,00 \\
\hline $\begin{array}{l}\text { kawasan wisata } \\
\text { Dibeli dalam kawasan } \\
\text { wisata }\end{array}$ & 15 & 15,00 \\
\hline $\begin{array}{l}\text { Dibawa dari luar dan } \\
\text { dibeli dalam kawasan } \\
\text { wisata }\end{array}$ & 46 & 46,00 \\
\hline Total & 100 & 100,00 \\
\hline
\end{tabular}

banyak dihasilkan oleh pelaku usaha makanan/minuman, yaitu $64,00 \%$ dari total sampah pelaku usaha. Hal ini terjadi karena jenis sampah yang dihasilkan pelaku usaha makanan/minuman lebih beragam dibandingkan dengan yang dihasilkan oleh pelaku usaha lainnya yang menghasilkan empat jenis sampah, yaitu barang plastik, bahan kertas, styrofoam, dan sampah organik.

Berdasarkan Tabel 2 dan Tabel 4, dapat disimpulkan bahwa jumlah sampah yang dihasilkan oleh wisatawan dalam satu tahun lebih banyak dari jumlah sampah yang dihasilkan oleh pelaku usaha dengan total bobot sampah keseluruhan sebesar 14.654, $93 \mathrm{~kg} / \mathrm{tah} u n$, sedangkan total bobot sampah dari pelaku usaha sebesar 2.253,93 kg/tahun. Potensi timbulan sampah didominasi oleh sampah yang berasal dari luar kawasan wisata, yang mencapai sebesar $53 \%$ dari total keseluruhan timbulan sampah. Hal ini dikarenakan wisatawan cenderung lebih banyak mengonsumsi makanan/minuman pada saat melakukan wisata di Pantai Tanjung Bira. Kesadaran wisatawan dalam mengelola sampah yang dihasilkan perlu ditingkatkan, dan mayoritas sampah yang dihasilkan oleh wisatawan adalah sampah plastik. Apabila sampah yang dihasilkan oleh wisatawan berserakan di kawasan Pantai Tanjung Bira maka hal tersebut akan mengganggu lingkungan sekitar, khususnya kenyamanan dalam berwisata.

Tabel 4 Rekapitulasi sampah berdasarkan sumber sampah di kawasan wisata Pantai Tanjung Bira

\begin{tabular}{lrrrr}
\hline \multirow{2}{*}{$\begin{array}{c}\text { Jenis } \\
\text { sampah }\end{array}$} & \multicolumn{2}{c}{ Wisatawan } & \multicolumn{3}{c}{ Pelaku usaha } \\
\cline { 2 - 5 } & $\begin{array}{c}\text { BS/Wisatawan } \\
\text { (kg/kunjungan) }\end{array}$ & $\%$ & $\begin{array}{l}\text { BS/unit } \\
\text { usaha } \\
\text { (kg/unit) }\end{array}$ & $\%$ \\
\hline $\begin{array}{l}\text { Barang } \\
\text { plastik }\end{array}$ & 0,020 & 45 & 7,080 & 57 \\
$\begin{array}{l}\text { Bahan } \\
\text { kaleng }\end{array}$ & 0,010 & 17 & 0,000 & 0 \\
$\begin{array}{l}\text { Bahan } \\
\text { kaca }\end{array}$ & 0,010 & 22 & 0,000 & 0 \\
$\begin{array}{l}\text { Bahan } \\
\text { kertas }\end{array}$ & 0,005 & 9 & 4,710 & 38 \\
$\begin{array}{l}\text { Styrofoam } \\
\text { Organik }\end{array}$ & 0,004 & 6 & 0,300 & 2 \\
\hline Total & 0,001 & 1 & 0,360 & 3 \\
\hline
\end{tabular}

Tabel 5 Nilai ekonomi sampah di kawasan wisata Pantai Tanjung Bira setelah diolah menjadi produk

\begin{tabular}{lrcr}
\hline \multicolumn{1}{c}{$\begin{array}{c}\text { Jenis } \\
\text { sampah }\end{array}$} & $\begin{array}{c}\text { Bobot setelah } \\
\text { proses } \\
\text { produksi }(\mathrm{kg})\end{array}$ & $\begin{array}{c}\text { Harga } \\
(\mathrm{Rp} / \mathrm{kg})\end{array}$ & $\begin{array}{c}\text { Nilai } \\
\text { ekonomi } \\
\text { (Rp/tahun) }\end{array}$ \\
\hline $\begin{array}{l}\text { Organik } \\
\begin{array}{l}\text { Plastik } \\
\text { Gelas } \\
\text { plastik }\end{array}\end{array}$ & 163,06 & 800 & 130.445 \\
$\begin{array}{l}\text { Kantong } \\
\text { kresek }\end{array}$ & 63,89 & 2.200 & 140.556 \\
\hline $\begin{array}{l}\text { Total } \\
\text { keseluruhan }\end{array}$ & 98,05 & 2.200 & 215.711 \\
\hline
\end{tabular}




\section{Perbandingan Jenis Sampah dari Wisatawan dan Pelaku Usaha di Kawasan Wisata Pantai Tanjung Bira}

Perbandingan setiap jenis sampah yang berasal dari wisatawan dan pelaku usaha perlu diketahui untuk melihat sumber sampah dan jenis sampah yang memiliki bobot terbesar atau sampah yang banyak dihasilkan di kawasan wisata Pantai Tanjung Bira. Perbandingan setiap jenis sampah berdasarkan sumbernya dapat dilihat pada Tabel 5 .

Berdasarkan Tabel 5, total bobot sampah yang bersumber dari responden wisatawan adalah sebesar $14.654,93 \mathrm{~kg} /$ tahun, sedangkan total bobot sampah yang berasal dari responden pelaku usaha adalah sebesar 2.253,93 kg/tahun. Akan tetapi, total bobot sampah yang disumbangkan oleh setiap wisatawan adalah $0,061 \mathrm{~kg} / \mathrm{orang} / \mathrm{kunjungan}$, yang lebih kecil dibandingkan dengan total bobot sampah yang dihasilkan oleh unit usaha, yaitu $12,45 \mathrm{~kg} / \mathrm{unit}$. Hal ini terjadi karena total bobot sampah responden wisatawan lebih banyak dengan jumlah populasi wisatawan yang lebih besar per tahun sehingga bobot sampah masing-masing wisatawan per sekali kunjungan lebih kecil dibandingkan dengan total bobot sampah dan jumlah populasi pelaku usaha.

Jenis sampah barang plastik pada kawasan wisata Pantai Tanjung Bira lebih dominan, baik yang berasal dari responden wisatawan, yaitu $45,00 \%$ dari total jumlah sampah dan dari pelaku usaha, yaitu 57,00\% dari total jumlah sampah. Persentase sampah bahan kaleng dan kaca lebih didominasi oleh sampah yang bersumber dari wisatawan dengan persentase masingmasing $17,00 \%$ dan $22,00 \%$, sedangkan pelaku usaha tidak menghasilkan sampah berbahan kaleng dan kaca tersebut. Jenis sampah bahan kertas lebih didominasi oleh sampah yang bersumber dari responden wisatawan, yaitu $9,00 \%$ dari total sampah wisatawan, sedangkan responden pelaku usaha hanya menyumbangkan jenis sampah bahan kerta sebesar $5,00 \%$ dari total sampah pelaku usaha. Jenis sampah styrofoam yang bersumber dari responden wisatawan hanya sebesar $6,00 \%$ dari total sampah wisatawan, sedangkan styrofoam yang bersumber dari responden pelaku usaha hanya sebesar $2,00 \%$ dari total sampah pelaku usaha. Jenis sampah organik yang bersumber dari responden wisatawan hanya sebesar $1,00 \%$ dari total sampah wisatawan, sedangkan sampah organik dari pelaku usaha mencapai $3,00 \%$ dari total sampah pelaku usaha.

Sumber sampah di kawasan wisata Pantai Tanjung Bira lebih didominasi oleh sampah yang berasal dari responden wisatawan. Jenis sampah yang bersumber dari wisatawan lebih bervariasi, yaitu jenis sampah barang plastik, bahan kaleng, kaca, kertas, styrofoam, dan sampah organik. Akan tetapi, jenis sampah yang bersumber dari wisatawan dengan persentase yang lebih besar adalah sampah plastik. Berdasarkan hasil wawancara dengan responden wisatawan, jenis sampah barang plastik yang dibawa dari luar kawasan wisata maupun dibeli di dalam kawasan wisata adalah gelas plastik, botol plastik, kemasan makanan, dan kantong kresek. Jenis sampah yang bersumber dari pelaku usaha adalah barang plastik, bahan kertas, styrofoam, dan bahan organik lainnya.

\section{Nilai Ekonomi Sampah di Kawasan Wisata Pantai Tanjung Bira}

Harga sampah di kawasan wisata Pantai Tanjung Bira diperoleh dengan mengacu pada harga sampah di bank sampah yang berada di Kabupaten Bulukumba. Jenis sampah anorganik di bank sampah di Kabupaten Bulukumba tidak semuanya dapat dijual oleh bank sampah sehingga terdapat jenis sampah yang tidak dihitung nilai ekonominya. Berdasrkan hasil identifikasi, jumlah jenis sampah yang dihasilkan di kawasan wisata Pantai Tanjung Bira mencapai 13 jenis sampah. Dari semua jenis sampah tersebut, $53,84 \%$ sampah yang belum memiliki harga jual dan $46,15 \%$ jenis sampah yang sudah memiliki harga jual. Jenis sampah yang sudah memiliki harga jual dan belum memiliki harga jual dapat dilihat pada Gambar 2.

Total nilai ekonomi sampah di kawasan wisata Pantai Tanjung Bira adalah sebesar Rp 20.298.215/tahun yang berasal dari sampah anorganik yang tidak diolah (berpotensi langsung dijual) $97,60 \%$, potensi plastik cacah $1,75 \%$, dan potensi kompos $0,64 \%$. Sampah organik yang dapat diproses menjadi kompos memiliki nilai ekonomi Rp130.445/tahun, dan jenis sampah plastik yang dapat diproses menjadi plastik cacah memiliki nilai ekonomi sebesar $R p$ 356.267/tahun. Rekapitulasi nilai ekonomi sampah kawasan wisata Pantai Tanjung Bira dapat dilihat pada Tabel 6.

Berdasarkan data pada Tabel 6, apabila sampah organik diproses menjadi bahan kompos akan mengalami penurunan bobot sebesar $60 \%$ dari bobot awal (Budihardjo 2006). Sampah organik tersebut yang sudah diolah menjadi kompos akan memiliki nilai ekonomi sebesar Rp130.445/tahun. Selain itu, sampah anorganik yang dapat diproses menjadi plastik cacah adalah gelas plastik dan kantong kresek. Rata-rata kapasitas cacahan plastik mengalami penurunan bobot sebesar 24\% dari bobot awal (Surtika et al. 2015). Dengan menggunakan pendekatan Benefit Transfer maka diperoleh nilai ekonomi sampah plastik setelah diolah menjadi plastik cacah sebesar $\mathrm{Rp}$ 356.267/tahun.

Selain, sampah yang dapat didaur ulang, terdapat pula sampah yang dapat dijual langsung. Beberapa jenis sampah yang dapat dijual langsung yaitu botol plastik, kaleng, dan kardus (Tabel 6).

Nilai ekonomi sampah anorganik yang dapat dijual langsung adalah sebesar Rp19.811.503/tahun. Jenis sampah bahan kaleng memiliki nilai ekonomi tertinggi, yaitu sebesar Rp12.099.707/tahun, meskipun total timbulan sampahnya tidak lebih besar dari botol plastik. Hal ini disebabkan karena jenis sampah kaleng tersebut memiliki harga jual yang cukup tinggi, yaitu Rp 5.000 dibandingkan dengan jenis sampah botol plastik. 


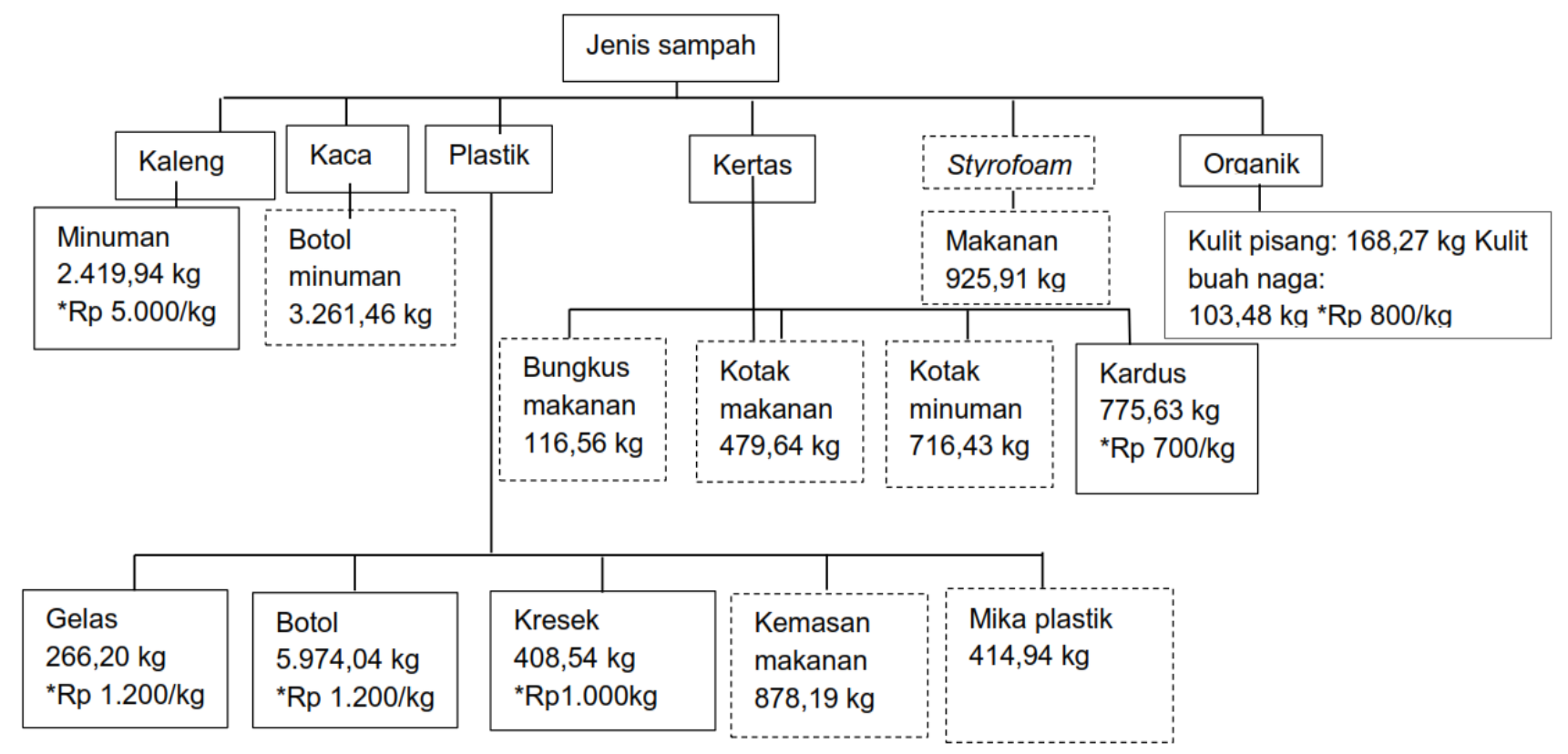

Gambar 2 Karakteristik sampah di kawasan wisata Pantai tanjung Bira. *) Acuan harga berasal dari Bank Sampah Mandiri Kabupaten Bulukumba (2019) dan

Tabel 6 Nilai ekonomi sampah di kawasan wisata Pantai Tanjung Bira yang dapat dijual langsung

\begin{tabular}{|c|c|c|c|}
\hline $\begin{array}{c}\text { Jenis } \\
\text { sampah }\end{array}$ & $\begin{array}{c}\text { Total timbulan } \\
\text { sampah } \\
\text { (kg/tahun) } \\
\end{array}$ & $\begin{array}{l}\text { Harga } \\
(\mathrm{Rp} / \mathrm{kg})\end{array}$ & $\begin{array}{c}\text { Nilai } \\
\text { ekonomi } \\
\text { (Rp/tahun) } \\
\end{array}$ \\
\hline \multicolumn{4}{|l|}{ Plastik } \\
\hline $\begin{array}{l}\text { Botol } \\
\text { plastik }\end{array}$ & $5.974,05$ & 1.200 & 7.168 .859 \\
\hline $\begin{array}{l}\text { Kaleng } \\
\text { Kertas }\end{array}$ & $2.419,94$ & 5.000 & 12.099 .707 \\
\hline $\begin{array}{l}\text { Kardus } \\
\text { makanan/ } \\
\text { minuman }\end{array}$ & 775,625 & 700 & 542.938 \\
\hline Total & $9.169,62$ & & 19.811 .503 \\
\hline
\end{tabular}

Potensi timbulan sampah pada kawasan wisata Pantai Tanjung Bira memiliki nilai ekonomi yang cukup besar. Berdasarkan hasil estimasi nilai ekonomi di atas, dapat dikatakan bahwa sampah akan menghasilkan atau menciptakan nilai ekonomi apabila dikelola dengan baik, artinya tidak hanya diangkut kemudian dibuang ke tempat pembuangan akhir. Sampah yang dijual langsung ataupun melalui proses pengolahan akan menghasilkan Resale Value yang penerimaannya dapat digunakan sebagai tambahan dana untuk pengelolaan sampah (Collecting Cost, Separating Cost, dan Processing Cost) dan pengembangan wisata di sana. Di samping itu, juga dapat mengurangi eksternalitas negatif yang dapat mengganggu ekosistem, keindahan, dan kenyamanan yang berpotensi menurunkan jumlah kunjungan sehingga dikhawatirkan dampak ekonomi yang dihasilkan dari aktivitas wisata tidak dapat berlanjut (sustainable). Artinya, selain adanya resale value, tapi juga ada biaya (external cost) yang dapat kita hindari (Avoid Cost) (Tietenberg 1998).

\section{KESIMPULAN}

Potensi timbulan sampah yang dihasilkan di kawasan wisata Pantai Tanjung Bira adalah sebesar $16.908,86 \mathrm{~kg} / \mathrm{tahun}$. Sumber sampah kawasan wisata Pantai Tanjung Bira lebih didominasi oleh sampah yang berasal dari wisatawan sebesar $87,00 \%$ dari total timbulan sampah. Jenis sampah yang bersumber dari wisatawan adalah jenis sampah barang plastik, bahan

kaleng, kaca, kertas, styrofoam, dan sampah organik. Sampah yang dihasilkan oleh pelaku usaha mencapai sebesar $13,00 \%$ dari total timbulan sampah. Jenis sampah yang bersumber dari pelaku usaha adalah barang plastik, bahan kertas, styrofoam, dan sampah organik. Potensi timbulan sampah di kawasan wisata Pantai Tanjung Bira lebih didominasi oleh sampah yang berasal dari luar kawasan wisata, yaitu sebesar $53 \%$ dari total timbulan sampah.

Total nilai ekonomi sampah kawasan wisata Pantai Tanjung Bira adalah Rp20.298.215/tahun, yang berasal dari sampah anorganik yang tidak diolah (berpotensi langsung dijual) sebanyak $97,60 \%$, potensi plastik cacah aebesar $1,75 \%$, dan potensi kompos sebesar $0,64 \%$. Nilai ekonomi sampah yang diolah menjadi kompos adalah sebesar Rp 130.445/tahun, nilai ekonomi sampah yang diolah menjadi plastik cacah adalah sebesar Rp 356.267/tahun, dan nilai ekonomi sampah yang dapat dijual langsung adalah yang paling besar, yaitu Rp 19.811.503/tahun.

\section{DAFTAR PUSTAKA}

Arianti D. 2014. Pengaruh Sektor Pariwisata Terhadap Perekonomian dan Keruangan Kota Bukittinggi 
(Pendekatan Analisis Input Output). Jurnal Wilayah dan Lingkungan. 2(3): 183-196. https://doi.org/ 10.14710/jwl.2.3.183-196

Asdiantri A, Fitrianingsih Y, Fitria L. 2016. Analisis Potensi Nilai Ekonomi Sampah Perumahan Kota Pontianak. Jurnal Teknologi Lingkungan Lahan Basa. 4(1): 1-10.

Budihardjo MA, 2006. Studi Potensi Sampah Kota sebagai Salah Satu Alternatif Pengelolaan Sampah di TPA dengan Menggunakan Aktivator EM4. Jurnal Presipitasi. 1(1): 25-30.

Crisdianti V. 2017. Alternatif Pengelolaan Sampah di Kawasan Wisata Laut Pesisir Taman Nasional Bromo Tengger Semeru. [skripsi]. Bogor (ID): Institut Pertanian Bogor.

Darmawi A. 2017. Potensi Timbulan Sampah Pada Objek Pariwisata Baru Di Kabupaten Bantul Yogyakarta. Jurnal Penelitian Teknologi Industri. 9(1): 61-71. https://doi.org/10.33749/ jpti.v9i1.2907

Fauzi A. 2014. Valuasi Ekonomi dan Penilaian Kerusakan Sumberdaya dan Lingkungan. Bogor (ID): IPB Press.

Hastuti P, Diah I. 2018. Analisis dampak wisata kampung pelangi terhadap peningkatan pendapatan masyarakat sekitar (pedagang) di Kelurahan Kemuning Kecamatan Banjarbaru Selatan. Jurnal IImiah Ekonomi Bisnis. 4(1): 29-35. https://doi.org/10.35972/jieb.v4i1.186

Maryono. 2017. Estimasi Daya Dukung Rekreasi untuk Pengelolaan Wisata Pantai Tanjung Bira Kabupaten Bulukumba Provinsi Sulawesi Selatan [tesis]. Bogor (ID): Institut Pertanian Bogor.

Maryono, Hefni E, Majariana K. 2016. Analisis Kepuasan Wisatawan untuk Manajemen Pantai di
Wisata Pantai Tanjung Bira. Jurnal Pariwisata. 3(2): 97-99.

Nurmansyah A. 2014. Potensi Pariwisata dalam Perekonomian Indonesia. Jurnal Ekonomi Bisnis \& Kewirausahaan. 3(1): 46-61.

Pertiwi N. 2014. Pengaruh Kunjungan Wisatawan, Retribusi Objek Wisata, dan PHR terhadap PD Kabupaten Gianyar. Jurnal Ekonomi Pembangunan. 3(3): 119.

Subadra I, Nadra N. 2006. Dampak Ekonomi, SosialBudaya, dan Lingkungan Pengembangan Desa Wisata di Jatiwulih-Tabanan. Jurnal Management dan Pariwisata II. 5(1): 57-61.

Sugiyono. 2010. Metode Penelitian Pendidikan Pendekatan Kuantitatif, Kualitatif, dan $R \& D$. Bandung (ID): Alfabeta.

Suharsaputra U. 2012. Metode Penelitian: Kuantitatif, Kualitatif, dan Tindakan. Bandung (ID): Refika Aditama.

Surtika M, Wijana M, Sudrajadinata M, 2015. Kajian Tekno Ekonomi Unit Alat Pencacah Plastik untuk Meningkatkan Nilai Jual Sampah Plastik: Studi Kasus-UD Sari Plastik Lombok Timur, NTB. Jurnal Dinamika Teknik Mesin. 5(2): 97-105. https://doi.org/10.29303/d.v5i2.35

Susilawati, Mappamiring, Said A. 2016. Strategi Pengembangan Pariwisata Pantai Bira sebagai Sumber Unggulan Pendapatan Asli di Daerah Kabupaten Bulukumba. Jurnal Administrasi Publik. 2(3): 352-364.

Tietenberg T. 1998. Environmental and Natural Resource Economics, 2nd Edition. Boston (US) : Scott, Foresman and Company 